\title{
PENINGKATAN PERKEMBANGAN KOGNITIF ANAK MELALUI MODEL PEMBELAJARAN TEAMS GAMES TOURNAMENT DENGAN MEDIA BALOK
}

\author{
Muflichah \\ Izatul Muwakidah \\ TK Pertiwi IV Lamongan \\ email:muflichah@gmail.com
}

Received August 2018, Accepted September 2018, Published October 2018

\begin{abstract}
The purpose of this research was to determine the improve cognitive development through cooperative learning methods type Teams Games Tournament (TGT) with beam media and geometric shapes of group A children at Pertiwi IV Kindergarten Lamongan. The research design used adopted a spiral model from the opinion of Kemmis and Mc. Taggart consist of four phase, planning, implementation, observation, and reflection. This research consists of two cycles, each cycle consisting of 3 meetings / actions. Data analysis uses quantitative and qualitative data. Quantitative data analysis with descriptive statistics is to compare the results obtained from the first cycle and the second cycle. While the analysis of qualitative data by analyzing data from the results of field notes and interviews during the research with the steps of data reduction, data display and data verification. The results showed an increase in cognitive development in the ability to classify colors and geometric shapes through the TGT learning model with beam media, it can be proved that the average score of pre-cycle cognitive development scores was $34.38 \%$. Then experienced an increase in the first cycle of $14.76 \%$ to $49.14 \%$. Furthermore, from cycle I to cycle II cognitive development of children increased by $2.93 \%$ from $49.14 \%$ to $52.07 \%$. So that the total increase in children's cognitive development starts from the pre-cycle, the first cycle to the second cycle is $34.38 \%$ which is $49.14 \%$ to $52.07 \%$
\end{abstract}

\section{Keywords: Cognitive Development, Learning Methods TGT, Beam Media}

\begin{abstract}
Abstrak: Peningkatan Perkembangan Kognitif Anak Melalui Model Pembelajaran TGT Dengan Media Balok. Penelitian ini bertujuan untuk: meningkatkan perkembangan kognitif melalui metode pembelajaran kooperatif tipe Team Game Tournament (TGT) dengan media bak pasir dan bentuk geometri anak kelompok A di TK Pertiwi IV Lamongan. Desain penelitian yang digunakan mengadopsi model spiral dari pendapat Kemmis dan Mc. Taggart melalui empat tahap yaitu perencanaan, pelaksanaan, pengamatan, dan refleksi. Penelitian ini terddiri dari dua siklus, masing-masing siklus terdiri dari 3 kali pertemuan/ tindakan. Analisis data menggunakan data kuantitatif dan kualitatif. Analisis data kuantitatif dengan statistik deskriptif yaitu membandingkan hasil yang diperoleh dari siklus pertama dan siklus kedua. Sedangkan analisis data kualitatif dengan cara menganalisis data dari hasil catatan lapangan dan wawancara selama penelitian dengan langkah-langkah reduksi data, display data dan verifikasi data. Hasil penelitian menunjukkan adanya peningkatan perkembangan kognitif dalam kemampuan klasifikasi warna dan bentuk geometri melalui model pembelajaran TGT dengan media balok, dapat dibuktikan rata-rata skor perkembangan kognitif pra siklus anak sebesar 34,38\%. Kemudian mengalami peningkatan pada siklus I sebesar $14,76 \%$ sehingga menjadi $49,14 \%$. Selanjutnya dari siklus I ke siklus II perkembangan kognitif anak mengalami peningkatan sebesar 2,93\% dari 49,14\% menjadi 52,07\%. Sehingga total peningkatan perkembangan kognitif anak mulai dari pra siklus, siklus I sampai siklus II $34,38 \%$ yaitu $49,14 \%$ menjadi $52,07 \%$.
\end{abstract}

Kata Kunci: Perkembangan Kognitif, Metode Pembelajaran TGT, Media Balok 


\section{PENDAHULUAN}

Pendidikan anak usia dini merupakan pendidikan yang menjadi gerbang awal memasuki pendidikan selanjutnya. Dengan melaksanakan pendidikan sedini mungkin maka pendidikan tersebut dapat menjadi investasi di masa depan, karena dengan pendidikan, kita dapat mengejar cita-cita di bidang yang diinginkan. Oleh karena itu, pendidikan yang baik salah satunya adalah pendidikan yang memperhatikan kepada minat dan bakat peserta didiknya. Pendidikan anak usia dini telah lama menjadi perhatian para orang tua, para ahli pendidikan, masyarakat dan pemerintah karena mengingat pentingnya pendidikan sejak dini.

Pendidikan anak usia dini adalah salah satu bentuk penyelenggaraan pendidikan yang menitikberatkan pada letakan dasar kearah pertumbuhan dan enam perkembangan yaitu; perkembangan moral dan agama, perkembangan fisik (koordinasi motorik kasar dan halus), kecerdasan/kognitif (daya pikir, daya cipta), sosio-emosional (sikap dan emosi), serta bahasa dan komunikasi, sesuai dengan keunikan dan tahap-tahap perkembangan sesuai kelompok usia yang dilalui oleh anak usia dini.

Sujiono mengemukakan bahwa "salah satu tujuan dari pengembangan kognitif diarahkan pada pengembangan geometri yang dapat dikembangkan melalui mencocokkan benda menurut warna,bentuk, dan ukurannya". Pembelajaran mengenal bentuk kepada anak harus menggunakan metode yang sesuai dengan perkembangan anak. Penerapan metode pembelajaran yang tidak tepat khususnya metode pembelajaran klasikal telah berdampak kepada menurunnya hasil belajar sebagian anak. Hal tersebut dianggap sebagai salah satu sumber kegagalan belajar, yang menjadikan anak cenderung pasif. Tuntutan kurikulum yang mengharuskan penyampaian materi secara total dengan target waktu tertentu mendorong timbulnya pemaksaan tenaga kependidikan kepada anak untuk menyelesaikan materi dengan percepatan tanpa memikirkan pemahaman, pengertian,dan pendalaman materi. Hal ini berdampak pada hasil belajar anak, menjadikan anak kurang tertarik terhadap pembelajaran, menganggap sulit, tidak kreatif danperkembangan anak menurun.

Selain itu, penerapan pembelajaran klasikal yang berorientasi kepada peningkatan pemahaman dan pendalaman materi akan berdampak kepada pembatasan materi yang diberikan. Jika anak diberikan kebebasan untuk menentukan tahap penguasaan terhadap pembelajaran, maka target kurikulum tidak akan tercapai dan berdampak kepada dangkalnya pengetahuan anak terhadap bidang pengembangan yang disampaikan.

Perkembangan dan peningkatan pengetahuan anak tidak lepas dari proses pembelajaran. Proses belajar mengajar diartikan sebagai kegiatan penyampaian informasi atau pengetahuan dari guru ke peserta didik. Namun, pada era modern ini perspektif mengajar mengalami perubahan paradigma, dari mengajar yang hanya sebatas menyampaikan materi pelajaran menjadi mengajar sebagai proses mengatur lingkungan.

Perubahan-perubahan makna dari mengajar terjadi karena pendidik bukan hanya menyampaikan materi pembelajaran atau hanya memberikan stimulus-stimulus kepada peserta didik, tetapi juga dipandang sebagai pengatur lingkungan agar peserta didik belajar sesuai dengan kemampuan dan potensi yang dimilikinya. Hal seperti ini, jelas menjadi masalah bagi para tenaga pengajar untuk memilih alternatif terbaik, jika metode pembelajaran klasikal masih tetap dipertahankan.

Rendahnya pemahaman sebagian anak dalam mengenal bentuk. Selain itu, penerapan konsep bentuk dalam prakteknya sulit dilakukan anak. Oleh karena itu anak tidak dapat mengetahui dan memahami dengan pasti bagaimana konsep bentuk. Selain itu lemahnya kreativitas guru menggunakan metode pembelajaran yang efektif dalam mengenalkan bentuk sehingga anak sulit memahami konsep bentuk dengan baik. Masalah lainnya adalah ketergantungan terhadap tenaga pengajar yang masih mendominasi sikap anak, khususnya dalam bidang pengembangan kognitif perlu diupayakan metode pembelajaran yang mendorong anak untuk lebih aktif, kreatif, tertantang dan menyenangkan dalam belajar. Salah satu model pembelajaran yang dipandang cocok untuk mengembangkan potensi anak dalam mengenal bentuk adalah model pembelajaran kooperatif tipe Teams Games Tournament (TGT).

Menurut Slavin penggunaan pembelajaran kooperatif bertujuan untuk meningkatkan pencapaian prestasi para siswa, dan juga akibat-akibat positif lainnya dapat 
mengembangkan hubungan antar kelompok, penerimaan terhadap teman sekelas yang lemah dalam bidang akademik, dan meningkatkan rasa harga diri. Model pembelajaran kooperatif merupakan suatu model pembelajaran dimana upaya-upaya berorientasi pada tujuan tiap individu menyumbang pencapaian individu lain guna mencapai tujuan belajar. Dalam belajar kooperatif, peserta didik tidak hanya mampu dalam memperoleh materi, tetapi juga mampu memberi dampak afektif seperti gotong royong, kepedulian sesama teman dan lapang dada. Sebab, di dalam pembelajaran kooperatif melatih peserta didik untuk bekerja secara bersama-sama dan saling membantu satu sama lain dalam mengintegrasikan pengetahuanpengetahuan baru dengan pengetahuan yang telah dimilikinya.

Pembelajaran kooperatif model TGT (Teams Games Tournaments) adalah salah satu tipe atau model pembelajaran kooperatif yang mudah diterapkan, melibatkan seluruh anak tanpa harus ada perbedaan status. Model pembelajaran ini melibatkan peran anak sebagai tutor sebaya, mengandung unsur permainan yang bisa menggairahkan semangat belajar dan mengandung reinforcement. Aktivitas belajar dengan permainan yang dirancang dalam pembelajaran kooperatif model TGT memungkinkan anak dapat belajar lebih rileks disamping menumbuhkan tanggung jawab, kejujuran, kerja sama, persaingan sehat dan keterlibatan belajar.

Model pembelajaran TGT (Teams Games Tournaments) merupakan salah satu bentuk upaya untuk meningkatkan berbagai perkembangan anak. Perkembangan anak dapat dibagi menjadi empat aspek yakni kognitif, sosial dan emosi, bahasa serta fisik/ motorik. Aspek-aspek perkembangan tersebut tidak berkembang secara sendiri-sendiri melainkan saling terintegrasi dan saling terjalin satu sama lainya. Dari berbagai aspek perkembangan di atas, perkembangan kognitif merupakan salah satu aspek yang penting untuk dikembangkan karena mempunyai tujuan mengembangkan kemampuan berpikir anak untuk dapat mengolah perolehan belajarnya, dapat menemukan berbagai alternatif pemecahan masalah, dapat membantu anak untuk mengembangkan kemampuan logika matematikanya dan pengetahuan akan ruang dan waktu serta mempunyai kemampuan mengelompokkan

dan mempersiapkan kemampuan berpikir teliti.

Piaget menyebutkan bahwa proses kognitif yang penting dalam otak anak adalah skema, asimilasi dan akomodasi, organisasi, serta ekuilibrasi. Skema dalam teori Piaget adalah tindakan atau representasi mental yang mengatur pengetahuan. asimilasi adalah masuknya informasi baru ke dalam pengetahuan yang sudah ada (skema). Akomodasi adalah penyesuaian skema agar sesuai dengan informasi dan pengetahuan baru.

Organisasi adalah pengelompokan perilaku yang terisolasi ke dalam sebuah sistem kognitif dengan susunan yang lebih tinggi yang berfungsi secara lebih lancar, pengelompokan atau penyusunan hal-hal ke dalam kategorikategori. Ekuilibrasi mekanisme yang diajukan Piaget untuk menjelaskan bagaimana anak-anak beralih dari satu tingkat pemikiran ke tingkat yang berikutnya.

Kognitif sering disebut kognisi mempunyai pengertian yang luas mengenai berpikir dan mengamati. Ada yang mengatakan bahwa kognitif adalah tingkah laku yang mengakibatkan orang memperoleh pengetahuan.

Berdasarkan pendapat para ahli diatas dapat disimpulkan bahwa perkembangan kognitif adalah proses interaksi dalam berperilaku yang mengakibatkan orang memperoleh pengetahuan, dalam hal tersebut terkait erat dengan perkembangan intelektual dan pertumbuhan mental.

Standar Tingkat Pencapaian Perkembangan Anak No. 136 menjelaskan bahwa terdapat beberapa indikatordalam lingkup perkembangan kognitif, diantaranya yaitu belajar dan pemecahan masalah, berfikir logis serta berfikir simbolik. Pada anak usia 4-5 tahun, indikator berfikir logis dijabarkan kembali dalam bentuk tingkat pencapaian, yaitu: mengklasifikasikan benda berdasarkan fungsi, bentuk, warna atau ukuran; mengenal gejala sebab akibat yang terkait dengan dirinya; mengklasifikasikan benda ke dalam kelompok yang sama atau kelompok yang sejenis atau kelompok yang berpasangan dengan 2 variasi; mengenal pola (missal $\mathrm{AB}-\mathrm{AB}$ dan $\mathrm{ABC}-\mathrm{ABC}$ ) dan mengulanginya; serta mengurutkan benda berdasarkan 5 seriasi ukuran atau warna.

Kemp (1995) menjelaskan bahwa model pembelajaran adalah suatu kegiatan pembelajaran yang harus dikerjakan guru dan 
anak agar tujuan pembelajaran dapat dicapai secara efektif dan efisien. Senada dengan pendapat di atas, Dick and Carey (1985) juga menyebutkan bahwa model pembelajaran itu adalah adalah suatu set materi dan prosedur pembelajaran yang digunakan secara bersamasama untuk menimbulkan hasil belajar pada anak.

Model pembelajaran adalah suatu desain atau rancangan yang menggambarkan proses rincian dan penciptaan situasi lingkungan yang memungkinkan anak berinteraksi dalam pembelajaran, sehingga terjadi perubahan atau perkembangan pada diri anak. Adapun komponen model pembelajaran meliputi: konsep, tujuan pembelajaran, materi/tema, langkahlangkah/prosedur, metode, alat/sumber belajar, dan teknik evaluasi.

Pengertian model pembelajaran kooperatif metode Team Game Tournament (TGT) menurut Hamdani adalah salah satu tipe atau model pembelajaran kooperatif yang mudah diterapkan, melibatkan aktivitas seluruh siswa tanpa ada perbedaan status, melibatkan peran siswa sebagai tutor sebaya, dan mengandung unsur permainan dan reinforcement. Aktivitas belajar dengan metode Team Game Tournament (TGT) memungkinkan siswa belajar lebih rileks di samping menumbuhkan tanggung jawab, kerja sama, persaingan sehat, dan keterlibatan belajar.

Salah satu upaya untuk meningkatkan perkembangan kognitif pada anak adalah dengan menggunakan model pembelajaran kooperatif tipe Teams Games Tournaments (TGT). Model pembelajaran TGT terdiri dari lima langkah yaitu: tahap penyajian kelas, belajar dalam kelompok, permainan, pertandingan dan penghargaan kelompok. Teams Games Tournaments (TGT) adalah salah satu tipe pembelajaran kooperatif yang mudah diterapkan, melibatkan aktivitas seluruh siswa tanpa harus ada perbedaan status, melibatkan peran siswa sebagai tutor sebaya dan mengandung unsur permainan dan penguatan.

Menurut Slavin (2008), pengaruh pembelajaran kooperatif terhadap pencapaian belajar anak mempunyai keunggulan dan kelemahan, sebagai berikut:

1. Para siswa di dalam kelas-kelas yang menggunakan TGT memperoleh teman yang secara signifikan lebih banyak dari kelompok rasial mereka dari pada siswa yang ada dalam kelas tradisional.

2. Meningkatkan perasaan/persepsi siswa bahwa hasil yang mereka peroleh tergantung dari kinerja dan bukannya pada keberuntungan.

3. TGT meningkatkan harga diri sosial pada siswa tetapi tidak untuk rasa harga diri akademik mereka.

4. TGT meningkatkan kekooperatifan terhadap yang lain (kerja sama verbal dan non verbal, kompetisi yang lebih sedikit).

5. Keterlibatan siswa lebih tinggi dalam belajar bersama, tetapi menggunakan waktu yang lebih banyak.

Cara bermain dalam model pembelajaran kooperatif tipe TGT (Team Games Tournament) yaitu dengan menempatkan anak dalam kelompok-kelompok belajar yang beranggotakan 5 sampai 6 orang yang memiliki kemampuan, jenis kelamin dan suku kata atau ras yang berbeda. Lalu guru memberikan penjelasan bahwa permainan tersebut merupakan permainan kompetitif, sehingga guru berharap anak dapat bermain dengan sikap sportif. Permainan berlangsung dengan cara anak mencari balok yang mempunyai bermacam warna dan bentuksesuai intruksi dari guru yang berada pada bak pasir yang telah disiapkan.

\section{METODE PENELITIAN}

Metode penelitian yang digunakan dalam penelitian ini adalah penelitian tindakan kelas (classroom action reseach) yang digunakan untuk memperbaiki mutu pendidikan di TK Pertiwi IV Lamongan. Penelitian tindakan kelas menurut Wina Sanjaya adalah proses pengkajian masalah pembelajaran di dalam kelas melalui refleksi diri dalam upaya untuk memecahkan masalah tersebut dengan cara melakukan berbagai tindakan yang terencana dalam situasi nyata serta menganalisis setiap pengaruh dari perlakuan tersebut.

Penelitian tindakan kelas ini dikemas dalam bentuk penelitian tindakan kelas kolaboratif, yang mana peneliti bekerja sama dengan guru kelas dalam melakukan penelitian baik merencanakan, mengobservasi, dan merefleksikan tindakan yang dilakukan untuk meningkatkan kualitas pembelajaran. Dengan demikian sejak perencanaan penelitian, peneliti senantiasa terlihat dan selanjutnya peneliti 
memantau, mengumpulkan data, menganalisis, serta melaporkan hasil penelitian dengan dibantu oleh kolabolator atau guru kelas. Desain penelitian yang digunakan mengadopsi model spiral dari pendapat Kemmis dan Mc. Taggart melalui empat tahap yaitu perencanaan, pelaksanaan, pengamatan, dan refleksi. Masingmasing tahapan mempunyai peran dan fungsinya.

Indikator penilaian keberhasilan PTK didasarkan kepada ketentuan sebagai berikut:

1. Kemampuan kognitif anak di kategorikan berhasil sangat baik (80 \%) jika anak benar dan tepat dalam mengklarifikasikan konsep warna, bentuk dan ukuran geometri.

2. Kemampuan kognitif anak dikategorikan berhasil dengan baik (70\%) jika anak benar namun kurang tepat dalam mengklasifikasikan konsep warna dan bentuk geometri.

3. Kemampuan kognitif anak dikategorikan berhasil dengan sedang $(60 \%)$ jika anak belum benar dan kurang tepat dalam mengklasifikasikan konsep warna dan bentuk geometri.

4. Kemampuan kognitif anak dikategorikan kurang baik (50\%) jika anak belum mampu dalam mengklasifikasikan konsep warna dan bentuk geometri.

Teknik pengumpulan data yang digunakan dalam penelitian ini adalah dokumentasi, wawancara, dan observasi. Dokumentasi dalam penelitian ini yaitu foto atau video mengenai apa yang dilakukan anak ketika dilakukan pembelajaran mengenai seriasi dan hasil kerja anak. Wawancara di lakukan kepada guru kelas secara terstruktur untuk mendapatkan data mengenai permasalahan yang ada di kelas dan penerapan pembelajaran kooperatif tipe TGT secara terstruktur sebagai upaya untuk meningkatkan perkembangan kognitif anak melalui media bak pasir dan balok geometri untuk mengklasifikasikan konsep warna, bentuk dan ukuran di TK Pertiwi IV Lamongan. Observasi dilakukan pada kelas yang dijadikan subyek penelitian untuk mendapatkan gambaran secara langsung kegiatan belajar anak dikelas. Dalam penelitian ini yang diamati adalah perkembangan kognitif pada anak kelompok A (usia 4-5 tahun) dengan indikator mengklasifikasikan konsep warna dan bentuk melalui media bak pasir dan balok geometri.
Kisi-kisi instrumen dikembangkan melalui definisi konseptual dan operasional yang menjelaskan bahwa perkembangan kognitif pada anak usia dini adalah suatu proses berfikir, kemampuan individu untuk menghubungkan, menilai, dan mempertimbangkan suatu kejadian atau peristiwa pada tahapan pra operasional, yaitu tahapan dimana anak belum menguasai operasi mental secara logis, ditandai dengan berkembangnya kemampuan untuk mewakili sesuatu yang lain dengan menggunakan simbolsimbol. Cara pemberian skor adalah melihat perkembangan kognitif anak dengan tingkatan: belum berkembang, mulai berkembang, berkembang sesuai harapan, dan berkembang sangat baik.

Pengolahan data dalam penelitian ini menggunakan dua jenis data, sesuai dengan tuntutan penelitian tindakan, yaitu data kualitatif dan kuantitatif. Analisis data penelitian menggunakan analisis data kuantitatif dengan statistik deskriptif. Analisa kuantitatif digunakan dengan cara membandingkan hasil yang diperoleh dari siklus pertama dan siklus kedua. Analisis data kualitatif dengan cara menganalisis data dari hasil catatan lapangan dan wawancara selama penelitian dengan langkah-langkah reduksi data, display data dan verifikasi data yang dilakukan dalam suatu proses.

\section{HASIL DAN PEMBAHASAN \\ Hasil}

Hasil penelitian menunjukkan bahwa perkembangan kognitif anak sudah mulai meningkat dari setiap pertemuannya dari tindakan pra siklus sampai siklus kedua.

\section{Pra Siklus}

Asesmen awal ini dilakukan untuk mengetahui kondisi awal perkembangan kognitif anak. Adapun hasil asessmen awal untuk perkembangan kognitif anak disajikan pada tabel 1 .

Dari data perkembangan kognitif anak pra-penelitian berdasarkan tabel 1, jika disajikan dalam bentuk grafik maka hasilnya dapat dilihat seperti pada gambar 1 . Berdasarkan grafik pada gambar 1 dapat diperoleh data tentang kemampuan kognitif anak pada pra siklus rata-rata yang diperoleh pada 25 anak yaitu persentase rata-rata tertinggi mencapai $34.38 \%$, dan persentase rata-rata terendah yaitu mencapai $25 \%$. 
Tabel 1 Hasil Asesmen Awal Pra-Siklus I Perkembangan Kognitif Anak

\begin{tabular}{|c|c|c|c|c|c|}
\hline $\begin{array}{c}\text { Nama } \\
\text { Anak }\end{array}$ & O1 & O2 & Skor & \% & Ket \\
\hline $\mathrm{Ri}$ & 18 & 21 & 19.5 & 30.5 & $\mathrm{MB}$ \\
\hline $\mathrm{Ar}$ & 20 & 19 & 19.5 & 30.5 & $\mathrm{MB}$ \\
\hline $\mathrm{Az}$ & 20 & 19 & 19.5 & 30.5 & $\mathrm{MB}$ \\
\hline $\mathrm{Hn}$ & 18 & 16 & 17 & 26.6 & $\mathrm{BB}$ \\
\hline $\mathrm{Vn}$ & 21 & 19 & 20 & 31.2 & $\mathrm{MB}$ \\
\hline $\mathrm{Fa}$ & 18 & 16 & 17 & 26.6 & $\mathrm{BB}$ \\
\hline $\mathrm{Ar}$ & 17 & 20 & 18.5 & 28.9 & $\mathrm{MB}$ \\
\hline $\mathrm{Al}$ & 21 & 18 & 19.5 & 30.5 & $\mathrm{MB}$ \\
\hline $\mathrm{Fr}$ & 17 & 18 & 17.5 & 27.3 & $\mathrm{BB}$ \\
\hline $\mathrm{Ul}$ & 21 & 20 & 20.5 & 32 & $\mathrm{MB}$ \\
\hline $\mathrm{Hr}$ & 23 & 21 & 22 & 34.4 & $\mathrm{MB}$ \\
\hline $\mathrm{Vi}$ & 21 & 19 & 20 & 31.3 & $\mathrm{MB}$ \\
\hline $\mathrm{De}$ & 21 & 19 & 20 & 31.3 & $\mathrm{MB}$ \\
\hline $\mathrm{Dt}$ & 18 & 18 & 18 & 28.1 & $\mathrm{MB}$ \\
\hline $\mathrm{Sv}$ & 16 & 17 & 16.5 & 25.8 & $\mathrm{BB}$ \\
\hline $\mathrm{Ad}$ & 16 & 17 & 16.5 & 25.8 & $\mathrm{BB}$ \\
\hline $\mathrm{Ul}$ & 19 & 17 & 18 & 28.1 & $\mathrm{MB}$ \\
\hline $\mathrm{Yy}$ & 22 & 20 & 21 & 32.8 & $\mathrm{MB}$ \\
\hline $\mathrm{At}$ & 19 & 16 & 17.5 & 27.3 & $\mathrm{BB}$ \\
\hline $\mathrm{Dn}$ & 16 & 16 & 16 & 25 & $\mathrm{BB}$ \\
\hline $\mathrm{Vv}$ & 21 & 21 & 21 & 32.8 & $\mathrm{MB}$ \\
\hline $\mathrm{Ww}$ & 20 & 20 & 20 & 31.3 & $\mathrm{MB}$ \\
\hline $\mathrm{Ll}$ & 20 & 16 & 18 & 28.1 & $\mathrm{MB}$ \\
\hline $\mathrm{Nd}$ & 21 & 20 & 20.5 & 32 & $\mathrm{MB}$ \\
\hline $\mathrm{Ft}$ & 20 & 20 & 20 & 31.2 & $\mathrm{MB}$ \\
\hline $\mathrm{Rata}$ \\
$\mathrm{rata}$ & 19. & 16. & 17.8 & 29.6 & $\mathrm{MB}$ \\
\hline & 2 & & & \\
\hline
\end{tabular}

\section{Siklus I}

Tahapan dalam membimbing anak yang mempunyai kemampuan di bawah rata-rata memang tidak mudah, perlu ketekunan dan cara-cara yang menarik. Demikian juga dalam hal meningkatkan kemampuan klasifikasi warna dan bentuk geometri pada anak.

Oleh karena itu peneliti ingin meningkatkan kemampuan klasifikasi warna dan bentuk geometri yang sangat penting bagi jenjang pendidikan selanjutnya untuk anak.

Setelah pemberian tindakan pada siklus 1, maka peneliti dan kolaborator melakukan assessmen terhadap kemampuan kognitif anak. Hal ini dilakukan untuk mengetahui skor yang diperoleh anak setelah pemberian tindakan pada siklus 1. Hasil assessmen setelah pemberian tindakan pada siklus 1 dapat dilihat pada tabel 2.

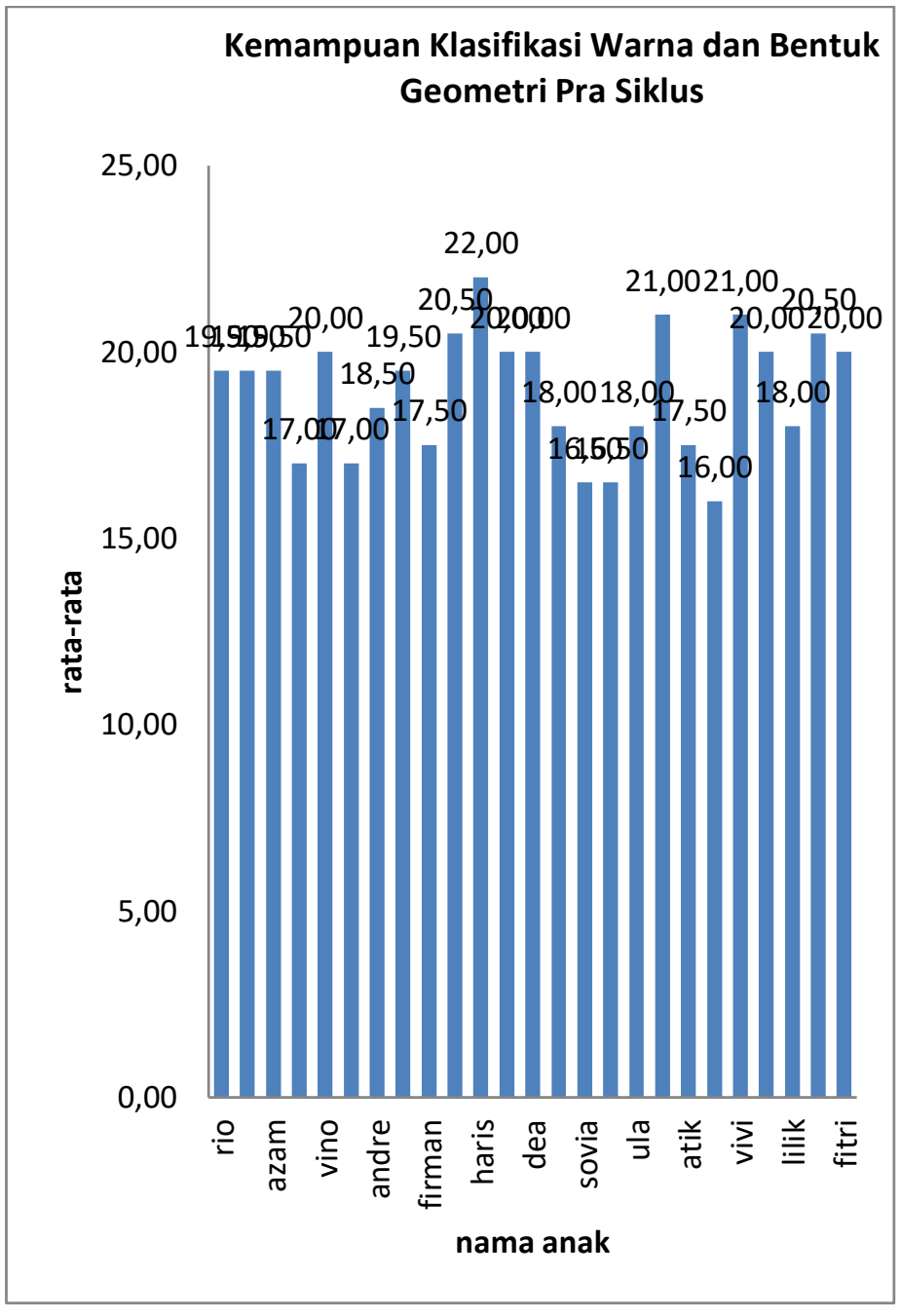

Gambar 1 Bagan Kemampuan Klasifikasi Warna dan Bentuk Geometri Pra Siklus

Berdasarkan data perkembangan kognitif anak setelah pelaksanaan siklus I berdasarkan tabel 2, jika disajikan dalam bentuk grafik maka hasilnya seperti yang disajikan pada gambar 2 .

Berdasarkan grafik pada gambar 2 dapat diperoleh data tentang kemampuan kognitif anak pada siklus 1 keseluruhan rata-rata yang diperoleh pada 25 anak yaitu 49.14\%. Sedangkan untuk persentase rata-rata tertinggi mencapai $51.82 \%$, dan persentase rata-rata terendah yaitu mencapai $43.23 \%$. 
144 Jurnal PG-PAUD Trunojoyo : Jurnal Pendidikan dan Pembelajaran Anak Usia Dini,

Volume 5, Nomor 2, Oktober 2018, hal 138 - 147

Tabel 2 Hasil Asesmen Awal Siklus I Perkembangan Kognitif Anak

\begin{tabular}{|c|c|c|c|c|c|}
\hline $\begin{array}{c}\text { Nama } \\
\text { Anak }\end{array}$ & O1 & O2 & Skor & \% & Ket \\
\hline $\mathrm{Ri}$ & 29.3 & 30 & 29.7 & 46.3 & $\mathrm{BSH}$ \\
\hline $\mathrm{Ar}$ & 32 & 32.7 & 32.3 & 50.5 & $\mathrm{BSH}$ \\
\hline $\mathrm{Az}$ & 32.3 & 31.7 & 32 & 50 & $\mathrm{BSH}$ \\
\hline $\mathrm{Hn}$ & 33 & 32.7 & 32.8 & 51.3 & $\mathrm{BSH}$ \\
\hline $\mathrm{Vn}$ & 32 & 31.7 & 31.8 & 49.7 & $\mathrm{BSH}$ \\
\hline $\mathrm{Fa}$ & 28.7 & 30 & 29.3 & 45.8 & $\mathrm{BSH}$ \\
\hline $\mathrm{Ar}$ & 31.7 & 31.7 & 31.7 & 49.5 & $\mathrm{BSH}$ \\
\hline $\mathrm{Al}$ & 31.7 & 32.3 & 32 & 50 & $\mathrm{BSH}$ \\
\hline $\mathrm{Fr}$ & 32 & 32.3 & 32.2 & 50.3 & $\mathrm{BSH}$ \\
\hline $\mathrm{Ul}$ & 33 & 33 & 33.1 & 51.8 & $\mathrm{BSH}$ \\
\hline $\mathrm{Hr}$ & 31.3 & 32 & 31.7 & 49.5 & $\mathrm{BSH}$ \\
\hline $\mathrm{Vi}$ & 33 & 32.3 & 32.7 & 51 & $\mathrm{BSH}$ \\
\hline $\mathrm{De}$ & 34.3 & 32.3 & 33.3 & 52.1 & $\mathrm{BSB}$ \\
\hline $\mathrm{Dt}$ & 30.7 & 32 & 31.3 & 49 & $\mathrm{BSH}$ \\
\hline $\mathrm{Sv}$ & 31.3 & 30.7 & 31 & 48.4 & $\mathrm{BSH}$ \\
\hline $\mathrm{Ad}$ & 28.3 & 29.3 & 28.8 & 45.1 & $\mathrm{BSH}$ \\
\hline $\mathrm{Ul}$ & 32.7 & 32.3 & 32.5 & 50.8 & $\mathrm{BSH}$ \\
\hline $\mathrm{Yy}$ & 29 & 30 & 29.5 & 46.1 & $\mathrm{BSH}$ \\
\hline $\mathrm{At}$ & 32.7 & 32.3 & 32.5 & 50.8 & $\mathrm{BSH}$ \\
\hline $\mathrm{Dn}$ & 32.3 & 33.3 & 32.8 & 51.3 & $\mathrm{BSH}$ \\
\hline $\mathrm{Vv}$ & 34.3 & 34 & 34.2 & 53.4 & $\mathrm{BSB}$ \\
\hline $\mathrm{Ww}$ & 30.3 & 30 & 30.2 & 47.1 & $\mathrm{BSH}$ \\
\hline $\mathrm{Ll}$ & 31.3 & 31.3 & 31.3 & 49 & $\mathrm{BSH}$ \\
\hline $\mathrm{Nd}$ & 31.7 & 31 & 31.3 & 49 & $\mathrm{BSH}$ \\
\hline $\mathrm{Ft}$ & 27 & 28.3 & 27.7 & 43.2 & $\mathrm{BSH}$ \\
\hline $\mathrm{Rata}$ & 31.4 & 31.5 & 31.4 & 49.1 & $\mathrm{BSH}$ \\
$\mathrm{rata}$ & & & & & \\
\hline & & & & & \\
\hline
\end{tabular}

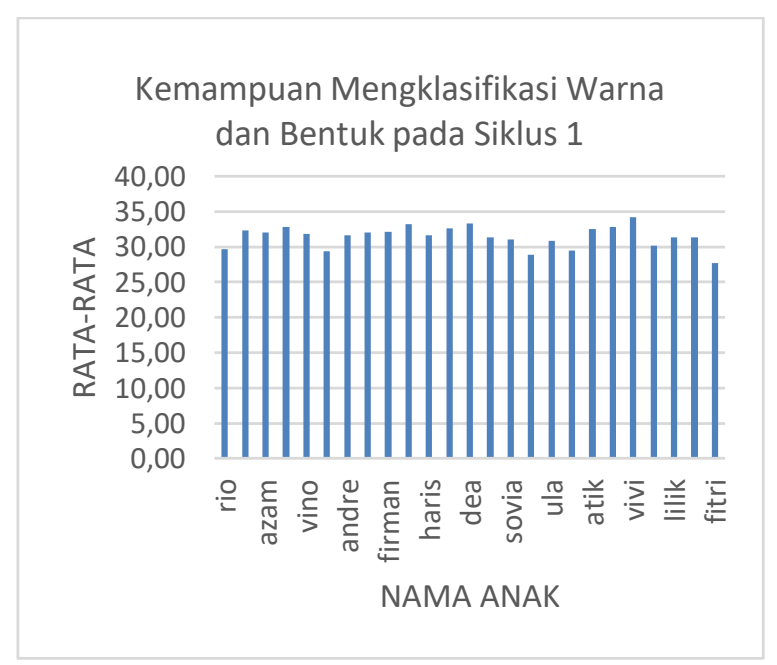

Gambar 2 Grafik Kemampuan Mengklasifikasi Warna dan Bentuk Geometri pada siklus 1
Siklus II

Tindakan yang akan dilakukan pada siklus 2 didasarkan pada hasil analisis dan refleksi siklus 1 . Pada umumnya kemampuan setiap anak sudah mengalami peningkatan, namun belum memuaskan. Untuk mengatasi kekurangan pada siklus 1 , peneliti dan guru melaksanakan diskusi untuk merencanakan tindakan pada siklus 2 yang rencananya akan dilakukan dalam tiga kali pertemuan. Setelah dilakukan tindakan pada siklus 2, jika dibandingkan dengan pra siklus dan siklus 1 presentase kemampuan anak mengalami peningkatan yang signifikan. Hal ini disebabkan karena guru kelas kosisten dalam menerapkan aturan pembelajaran dan membuat pembelajaran menjadi menarik, sehingga anakanak merasa senang dan tidak bosan. Hasil assessmen setelah pemberian tindakan pada siklus 2 dapat dilihat pada tabel 3 .

Tabel 3 Hasil Asesmen Awal Siklus II Perkembangan Kognitif Anak

\begin{tabular}{|c|c|c|c|c|c|}
\hline $\begin{array}{c}\text { Nama } \\
\text { Anak }\end{array}$ & O1 & O2 & Skor & \% & Ket \\
\hline $\mathrm{Ri}$ & 34.7 & 35 & 34.8 & 54.4 & $\mathrm{BSB}$ \\
\hline $\mathrm{Ar}$ & 34.3 & 32.7 & 33.5 & 52.3 & $\mathrm{BSB}$ \\
\hline $\mathrm{Az}$ & 32.7 & 32.7 & 32.7 & 51 & $\mathrm{BSH}$ \\
\hline $\mathrm{Hn}$ & 32.7 & 32.7 & 32.8 & 51.3 & $\mathrm{BSH}$ \\
\hline $\mathrm{Vn}$ & 34 & 32.7 & 33.3 & 52.1 & $\mathrm{BSB}$ \\
\hline $\mathrm{Fa}$ & 32 & 31.7 & 31.8 & 49.7 & $\mathrm{BSH}$ \\
\hline $\mathrm{Ar}$ & 32.3 & 32.3 & 32.3 & 50.5 & $\mathrm{BSH}$ \\
\hline $\mathrm{Al}$ & 32.3 & 33.3 & 32.8 & 51.3 & $\mathrm{BSH}$ \\
\hline $\mathrm{Fr}$ & 33.3 & 34.3 & 33.8 & 52.9 & $\mathrm{BSB}$ \\
\hline $\mathrm{Ul}$ & 33 & 33 & 33.1 & 51.8 & $\mathrm{BSH}$ \\
\hline $\mathrm{Hr}$ & 31.7 & 33.3 & 32.5 & 50.8 & $\mathrm{BSH}$ \\
\hline $\mathrm{Vi}$ & 33.7 & 33.3 & 33.5 & 52.3 & $\mathrm{BSB}$ \\
\hline $\mathrm{De}$ & 35 & 35.3 & 35.2 & 54.9 & $\mathrm{BSB}$ \\
\hline $\mathrm{Dt}$ & 32.3 & 32.7 & 32.5 & 50.8 & $\mathrm{BSH}$ \\
\hline $\mathrm{Sv}$ & 33.3 & 34.3 & 33.8 & 52.9 & $\mathrm{BSB}$ \\
\hline $\mathrm{Ad}$ & 31.7 & 31.7 & 31.7 & 49.5 & $\mathrm{BSH}$ \\
\hline $\mathrm{Ul}$ & 32.7 & 32 & 32.3 & 50.5 & $\mathrm{BSH}$ \\
\hline $\mathrm{Yy}$ & 33.3 & 34.3 & 33.8 & 52.8 & $\mathrm{BSB}$ \\
\hline $\mathrm{At}$ & 34.3 & 32.3 & 33.3 & 52.1 & $\mathrm{BSB}$ \\
\hline $\mathrm{Dn}$ & 34 & 34.7 & 34.3 & 53.7 & $\mathrm{BSB}$ \\
\hline $\mathrm{Vv}$ & 35.7 & 36.7 & 34.3 & 53.6 & $\mathrm{BSB}$ \\
\hline $\mathrm{Ww}$ & 31.3 & 31.7 & 31.5 & 49.2 & $\mathrm{BSH}$ \\
\hline $\mathrm{Ll}$ & 33 & 33 & 33 & 51.6 & $\mathrm{BSH}$ \\
\hline $\mathrm{Nd}$ & 34.7 & 33.7 & 34.2 & 53.4 & $\mathrm{BSB}$ \\
\hline $\mathrm{Ft}$ & 36 & 35 & 35.5 & 55.5 & $\mathrm{BSB}$ \\
\hline $\begin{array}{c}\mathrm{Rata} \\
\mathrm{rata}\end{array}$ & 33.4 & 33.3 & 33.3 & 52.1 & $\mathrm{BSB}$ \\
\hline & & & & & \\
\hline
\end{tabular}




\section{KEMAMPUAN MENGKLASIFIKASI \\ WARNA DAN BENTUK GEOMETRI \\ PADA SIKLUS 2}

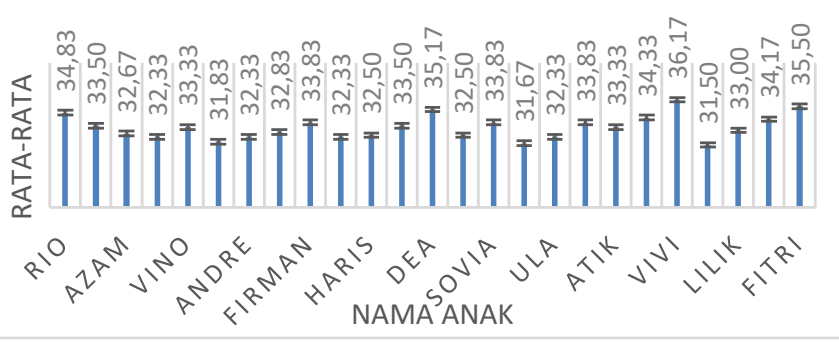

\section{Gambar 3 Grafik Kemampuan Mengklasifikasi Warna dan Bentuk Geometri pada siklus 2}

Berdasarkan data perkembangan kognitif anak setelah siklus II pada tabel 3, jika disajikan dalam bentuk grafik maka hasilnya dapat dilihat seperti pada gambar 3 .

Berdasarkan grafik pada gambar 3 dapat diperoleh data tentang kemampuan kognitif anak pada siklus 2 keseluruhan rata-rata yang diperoleh pada 25 anak yaitu $52.07 \%$. Sedangkan untuk persentase rata-rata tertinggi mencapai $55.47 \%$, dan persentase rata-rata terendah yaitu mencapai $49.22 \%$.

\section{Pembahasan}

Berdasarkan hasil temuan-temuan penelitian tentang kegiatan mengklasifikasikan warna dan bentuk geometri dalam bak pasir menggunakan model pembelajaran TGT (teams games tournament), bahwa kegiatan tersebut dapat meningkatkan kemampuan kognitif anak. Hal ini dapat dilihat bahwa ada peningkatan dalam kemampuan mengklasifikasikan warna dan bentuk geometri di kelompok A TK Pertiwi IV Lamongan. Meningkatnya kemampuan klasifikasi warna dan bentuk geometri anak didukung oleh beberapa faktor hasil temuan peneliti saat melaksanakan kegiatan pengamatan atau penelitian di lapangan, diantaranya yaitu:

1. Sebelum melaksanakan kegiatan pembelajaran sebaiknya guru memberikan penjelasan tentang kegiatan yang akan dilaksanakan dengan jelas agar mudah dimengerti oleh anak,

2. Guru sebaiknya memberikan pengarahan atau bimbingan pada anak yang masih suka bermain dalam kelas saat kegiatan pembelajaran sedang berlangsung,

3. Guru lebih sering mengajak anak berbincang-bincang sebelum melaksanakan kegiatan,

4. Guru menyampaikan langkah-langkah kegiatan secara berulang-ulang agar dipahami oleh anak,

5. Guru meningkatkan perhatian melalui bimbingan terhadap anak yang mengalami kesulitan saat melakukan kegiatan,

6. Guru memiliki kegiatan pembelajaran yang kreatif dan inovatif,

7. Memberikan motivasi pada anak agar anak bersemangat saat melakukan kegiatan pembelajaran,

8. Memberikan pujian kepada anak yang sudah menyelesaikan dan mengikuti kegiatan pembelajaran dengan baik dan tertib.

Selama peneliti melakukan penelitian terhadap 25 anak, terdapat 13 anak yang mengalami peningkatan kemampuan klasifikasi warna dan bentuk dengan kriteria Berkembang Sangat Baik (BSB), yaitu Rio, Ardi, Vino, Firman Vian, Dea, Sovia, Yaya, Atik, Diana, Vivi, Nada, dan Fitri. Sedangkan 12 anak lainnya mengalami peningkatan kemampuan klasifikasi warna dan bentuk dengan kriteria Berkembang Sesuai Harapan (BSH), yaitu Azam, Hendri, Fais, Andre, Aal, Ulil, Haris, Dita, Adel, Ula, Wiwin dan Lilik.

Berdasarkan hasil analisis dan pembahasan yang telah dijelaskan di atas, dapat disimpulkan bahwa secara umum kegiatan permainan klasifikasi warna dan bentuk geometri dalam bak pasir menggunakan model pembelajaran kooperatif tipe TGT dapat meningkatkan perkembangan kognitif. Sedangkan secara khusus permainan ini dapat meningkatkan aspek berfikir logis yaitu mengklasifikasikan warna dan bentuk.

Seperti yang telah disepakati antara peneliti dan kolaborator bahwa indicator keberhasilan sebesar $80 \%$, akan tetapi, jika belum mencapai presentasi rata-rata $80 \%$ maka akan dilanjutkan di siklus berikutnya.

Pada siklus 1 dilihat dari pelaksanaan masih ada anak yang belum meningkat kemampuan klasifikasikan warna dan bentuk geometri. Dan dalam siklus ini ada penigkatan kemampuan mengklasifikasikan warna 
dibandingkan sebelum tindakan. Hal ini dikarenakan guru kelas jarang menggunakan metode permainan klasifikasi dalma proses kegiatan. Sehingga anak senang dan antusias saat kegiatan.

Berdasarkan hasil refleksi kembali agar kemampuan kognitif anak dapat meningkat. Bedasarkan hasil asessmen rata-rata yang diperoleh pada 25 anak yaitu 49,14\%. Sedangkan untuk presentase rata-rata tertinggi mencapai $51,82 \%$. Dan presentase rata-rata terendah yaitu mencapai $43.23 \%$.

Kemampuan kognitif penting bagi anak. Untuk itu perlu adanya peningkatan. Sebelum adanya upaya peningkatan, kemampuan mengklasifikasi warna dan bentuk geometri sudah berkembang tetapi belum memuaskan. Sehingga peneliti dan kolaborator membuat suatu kegiatan untuk meningkatkan kemampuan mengklaisifikasi warna dan bentuk geometri pada anak. Disimpulkan bahwa dalam siklus 1 pada umumnya anak sudah mengalami peningkatan tetapi belum memuaskan. Jadi, untuk mengatasi akan dilakukan tindakan pada siklus 2 .

Pada siklus 2 ini, dilihat dari pelaksanaan yaitu kegiatannya sama dengan siklus 1 akan tetapi dalam siklus 2 ini akan dibuat sebuah kompetisi agar peneliti dapat mengamati sejauh mana kemampuan anak dan sejauh mana berkembangnya.

Dilihat dari analisis dan refleksi mengalami peningkatan dibanding dengan tindakan dan tindakan pada siklus 1. Dan presentase kemampuan anak mengalami peningkatan yang signifikan Dengan rata-rata yang diperoleh pada 25 anak yaitu 52,07\% sedangkan untuk prosentase rata-rata tertinggi mencapai $55.47 \%$ dan presentase terendah ratarata yaitu mencapai $49.22 \%$.

Dilihat dari kajian neurosains ilmu ini sangatlah penting dan berguna untuk mengenali perkembangan dan kemampuan anak,terutama yang berada di usia golden age,yaitu 0-6 tahun. Neurosains merupakan suatu kajian mengenai saraf yang ada dalam otak manusia. Pendidikan berbasis otak menempatkan otak untuk lebih dirangsang karena otak anak akan berkembang jika diberi rangsangan ataupun sentuhan dari luar.pendidikan anak usia dini pembeljarannya tidak terlalu formal dan membebaskan anak untuk mengembangkan kognitifmya melalui permainan bak pasir.
Dari sudut pandang pedagogik. Guru mampu menetapkan berbagai pendekatan, strategi,metode,dan teknik pembelajaran yang mendidik secara kreatif dan efektif sesuai dengan standart kompetesi guru. Menurut suwarno istilah pendagogik berarti pendidikan, yang lebih menekankan kepada praktek, menyangkut kegiatan mendidik,kegiatan membimbing anak. Guru mampu menyesuaikan metode pembelajaran yang sesuai dengan karakteristik peserta didik dan mampu memotivasi mereka untuk belajar. Hal tersebut menjadi seorang guru anka usia dini dituntut untuk menjadi guru yang aktif, kreatif dan efektif dalma menyajikan kegiatan unik yang dapat mengembangkan kemampuan kognitif pada anak.

Dari sudut pandang motorik Perkembangan fisik sangat terkait erat dengan perkembangan motorik anak. Perkembangan motorik merupakan perkembangan dari unsur kematangan dan pengendalian gerakan tubuh yang erat kaitannya dengan perkembangan pusat motorik di otak. Hurlock (2000) mengatakan bahwa perkembangan motorik adalah perkembangan gerakan jasmaniah melalui kegiatan pusat syaraf, urat syaraf, dan otot yang terkoordinasi.

Jadi, perkembangan motorik merupakan kegiatan yang terkoordinir antara susunan saraf, otot, otak, dan spinal cord. Perkembangan motorik adalah proses yang sejalan dengan bertambahnya usia secara bertahap dan berkesinambungan, dimana gerakan individu meningkat dari keadaan sederhana, tidak terorganisir, dan tidak terampil, ke arah penguasaan keterampilan motorik yang kompleks dan terorganisasi dengan baik.

\section{SIMPULAN}

Berdasarkan hasil penelitian dan pembahasan yang telah dikemukakan dapat diperoleh kesimpulan bahwa pelaksanaan pada siklus 1 menggunakan media bak pasir dan bentuk geometri.serta mencari bentuk geometri didalam pasir serta mencocokkan bentuk tersebut dengan bentuk geometri yang lain berdasarkan bentuk,dan warna yang sama.dari hasil refleksi siklus 1 pene;iti dan kolaborator akan melakukan siklus 2 karena saat tahap 1 anak masih kurang tepat mecocokan bentuk dan warna. Pada siklus 2 tetap sama menggunakan media bak pasir dan bentuk geometri dengan 
cara kompetisi.jika ada yang menang akan memperoleh reward.

kegiatan model pembelajaran kooperatif tipe Team Games Tournament (TGT) dengan menggunakan media bak pasir dan bentuk geometri di TK PERTIWI IV dapat meningkatkan perkembangan kognitif anak. Hal ini dapat dilihat dari kondisi awal pra siklus anak dengan rata-rata yang diperoleg 25 anak yaitu presentase tertinggi mencapai $34.38 \%$ dan presentase rata-rata terendah mencapai $25.00 \%$. setelah dilakukan siklus 1 anak yang berada pada kategori rendah mulai meningkat dengan prosentase rata-rata 25 anka yaitu $49.14 \%$. dengan presentase rata-rata tertinggi $51.82 \%$ dan prosentase rata-rata terendah mencapai 42.23\%. siklus 1 dikatakan meningkat tetapi belum memuaskan. Dan selanjutnya di lakukan siklus 2 dengan prosentase rata-rata semua 25 anak yaitu $50.07 \%$ dengan prosentase rata-rata tertinggi yaitu mencapai $55.47 \%$ dan prosentase terendah yaitu mencapai $49.22 \%$. dan di siklus 2 ini terjadi peningkatan yang signifikan.

\section{Saran}

Berdasarkan hasil penelitian, peneliti mengemukakan beberapa saran sebagai berikut, sekolah hendaknya memberikan kegiatan meningkatkan perkembangan kognitif anak melalui metode pembelajaran tipe Team Games Tournament (TGT). Dapat meningkatkan kognitif anak secara optimal dan penyediaan sarana prasarana yang lengkap dapat menunjang kegiatan ini. Bagi orang tua hendaknya lebih kreatif dalam memberikan permainan edukatif sehingga dapat meningkatkan perkembangan kognitif anak.

\section{DAFTAR PUSTAKA}

Arikunto, S. 1998. Prosedur Penelitian Suatu Pendekatan Praktek. Jakarta : Rineka Cipta.

Beaty. J., J. 2013. Observasi Perkembangan Anak Usia Dini. Jakarta: Kencana Prenadamedia Group.

Desmita. 2013. Psikologi Perkembangan. Bandung: PT. Remaja Rosdakarya.
Feldman, P., O. 2009. Human Development Edisi 10 Buku 1. Jakarta: Salemba Humanika.

Franc. A. Y. 2014. Rahasia Otak \& Kecerdasan Anak. Yogyakarta: Teranova Books.

Hamdani. 2011. Strategi Belajar Mengajar. Bandung: Pustaka Setia.

Hurlock, E., B. 1978. Perkembangan Anak Jilid 1. Jakarta: Erlangga.

Hurlock, E., B. 1993. Perkembangan Anak Jilid 1. Jakarta: Erlangga.

Jahja, Y. 2011. Psikologi Perkembangan. Jakarta: Prenada Media Group.

Rusman. 2013. Model-Model Pembelajaran (Mengembangkan Profesionalisme Guru). Jakarta: PT Raja Grafindo Persada.

Sadullah, U., dkk. 2011. Pendagogik. Bandung:Alfabeta.

Santrock, J., W. 2007. Perkembangan Anak Jilid 2. Jakarta: Erlangga.

Santrock, J. W. 2009. Psikologi PendidikanEducational Psycology terjemahan Diana Angelica. Jakarta: Salemba Humanika.

Slavin, R. E. 2008. Cooperative Learning: Teori, Riset dan praktik. Bandung: Nusa Media..

Sujiono, Y. N. 2009. Konsep Dasar Pendidikan Anak Usia Dini. Jakarta: PT. Indeks. 